\title{
The Status of the Narrator in Modernist Fiction
}

1. 'The empty centre'

In an essay from 1987, Banfield identifies a peculiar narrative technique which involves consciousness presentation, but exhibits some paradoxical characteristics. Although not widespread, the phenomenon of what she calls 'the empty centre' is complex enough to merit closer theoretical analysis, but in spite of this it has not been the subject of much further discussion. Banfield's examples of 'the empty centre' are mostly drawn from Virgina Woolf's The Waves and include sentences such as:

The sun had now sunk lower in the sky (Woolf, The Waves, 155).

The tree, that had burnt foxy red in spring and in midsummer bent pliant leaves to the south wind, was now black as iron, and as bare (Woolf, The Waves, 178; cited in Banfield, 1987: 273).

As examples of free indirect style, marked by the past perfect ('had sunk', 'had burnt'), used without any past simple reference point in the sentence, and by the present time deixis ('now'), co-extensive with the past of the narrative, the sentences present a case of represented perception (Brinton, 1980; Sotirova, 2013; Rundquist, 2014). They invite an interpretation of someone present in the narrative world who observes the phenomena of this world. But there is no observing consciousness on stage to which we can attribute the perceptions in such sentences. They appear in the narrative sections of The Waves which Woolf calls 'interludes' and which separate sections of what she calls 'dramatic soliloquies' of several characters. Thematically, they are connected because both the interludes and the dramatic soliloquies discuss sense impressions, but the only trace of a narratorial voice in the book are the inquit formulas of the most minimal kind: 'said Bernard', 'said Rhoda', 'said Susan'.

This kind of sentence, unanchored into a character's consciousness, but richly expressive of a subjectivity is, according to Banfield, 'centred in an empty here and now', hence her identification as 'an empty centre', and 'become[s] [...] the appropriate linguistic representation of the unobserved, here and now defining the Russellian perspective, that physical subjectivity which may remain impersonal', or in Woolf's words, quoted by Banfield 'the world without a self' (1987: 274).

Because, according to Banfield, the technique represents a physical perception only, she talks about a physical subjectivity that is both implied by the narrative language and absent at the same time. Banfield's theory of 'the empty centre' only permits sentences of represented perception to be included in the technique. Represented perception is one of the modes of free indirect style (Banfield, 1981; Brinton, 1980; Sotirova, 2013; Rundquist, 2014) and is linguistically marked by certain indices of subjectivity, most characteristically deixis and verbal aspect (Adamson, 1994), while typically disallowing other linguistic features of subjectivity which imply a more conscious and reflective awareness, such as evaluative language. According to Banfield, the 'empty centre' technique typically manifests in sentences containing 'place and time deictics, here and now or their equivalents; they might also contain demonstratives designating sensibilia. But they would not contain those subjective elements and constructions implying the mental states of a personal subject' (Banfield, 1987: 273), because no such subjectivity is present on stage. So, features such as 
'embeddable subjective elements such as nouns or adjectives "of quality" representing a subject's opinions, feelings or thoughts, as well as non-embeddable subjective elements such as exclamations', or 'any third person pronoun representing a subjectivity' (Banfield, 1987: 273) would be prohibited from appearing in sentences of the 'empty centre' technique.

This subjective language without a subjectivity is explained by Banfield in philosophical terms, using 'Russell's theory of sensibilia':

In this theory of knowledge, knowledge of the external world is built upon a solipsistic basis, but an impersonal solipsism which replaces Cartesian privacy by instrumental privacy, a private here-now emptied of the person of any observer but in which a this nonetheless appears (Banfield, 1987: 276).

The sentence that records the oxymoron of Banfield's impersonal subjectivity is something like 'this was now being recorded' or 'this triangle was now occurring', or 'The sun had now sunk lower in the sky'. This kind of sentence is the equivalent of the photographic plate, or in Barthes' terms, to which Banfield also alludes, 'the light-sensitive film which stands in the place of $\mathrm{me}^{\prime}$, a human observer (Banfield, 1987: 277).

It is to Banfield's credit to have drawn attention to such paradoxical examples of subjective representations of consciousness in the absence of a subject. The discussion of 'the empty centre' is taken further by Fludernik $(1993,1996)$ who challenges Banfield's claim that 'the empty centre' sentence can only be one of physical perception. Although this is the case in the majority of examples, including the ones Banfield chooses to illustrate the phenomenon - the majority from Woolf's The Waves - Fludenrik brings further evidence to the debate. This type of sentence of represented perception displays linguistic features of perceptual experience - temporal and spatial deixis and aspectual nuances. But even in these strictly perceptual examples of free indirect style, it is not possible to always steer clear of evaluation, which for Banfield would be evocative of a reflective consciousness. Banfield strategically quotes only one sentence at a time, but if extended, the context for one of her examples shows that evaluation is inherent even into the physical description:

The sun had now sunk lower in the sky. The islands of cloud had gained in density and drew themselves across the sun so that the rocks went suddenly black, and the trembling seaholly lost its blue and turned silver, and shadows were blown like grey cloths over the sea (Woolf, The Waves, 155).

The particularly lyrical quality of the passage is suggestive of an observing consciousness that can and does reflect to an extent on what is seen: there is only a fine line between descriptive and evaluative adjectives and the highly poetic simile is also suggestive of some level of reflection beyond pure perception. Fludernik argues a similar point on the basis of the presence of modal adverbs like 'perhaps' and the perception verb 'seem', which as she points out, 'require the presence of a reflective (not a non-reflective) consciousness', according to Banfield's own model of reflective and non-reflective consciousness (Fludernik, 1996: 197).

Fludernik, bringing into the discussion other literary examples, shows that 'the empty centre' technique displays much more densely subjectivity features that are associated with a reflective 
consciousness and so it no longer fits into the neat philosophical categorisation of a style that describes the world as 'seen without a self', or simply reflects it as a photographic plate.

One of the classic examples of 'the empty centre' technique is the opening of Katherine Mansfield's short story 'At the Bay':

Very early morning. The sun was not yet risen, and the whole of Crescent Bay was hidden under a white sea-mist. The big bush-covered hills at the back were smothered. You could not see where they ended and the paddocks and bungalows began. The sandy road was gone and the paddocks and bungalows the other side of it; there were no white dunes covered with reddish grass beyond them; there was nothing to mark which was beach and where was the sea. A heavy dew had fallen. The grass was blue. Big drops hung on the bushes and just did not fall; the silvery, fluffy toi-toi was limp on its long stalks, and all the marigolds and the pinks in the bungalow gardens were bowed to the earth with wetness.

Drenched were the cold fuchsias, round pearls of dew lay on the flat nasturtium leaves. It looked as though the sea had beaten up softly in the darkness, as though one immense wave had come rippling, rippling - how far? Perhaps if you had waked up in the middle of the night you might have seen a big fish flicking in at the window and then gone again... (Mansfield, 'At the Bay', 201).

Fludernik, who also quotes the first paragraph of the opening highlights the emboldened phrases as significant for interpreting the passage as free indirect style. In relation to the whole opening of the story, extending over two and a half pages, she explains that it 'is saturated with consciousness signals: character-deixis (at the back; beyond; there ahead); come and appear as indices of textinternal perception; seem and look to indicate a figural subjectivity; something to mark the perceiver's inability to recognize the perceived object; subjective evaluative lexis (giant - for a tree; marvellous; the darling little woolly lambs); tense indicators of figural perception ("The sun was not yet risen"; "The sun was rising"; "now they had passed"); signals of actual perception ("out of sight", "you could not see")' (Fludernik, 1993: 390). In the quoted passage, in addition to Fludernik's annotations, we find the deictic 'yet' and 'the other side' and some further examples of the past perfect - 'had beaten up' and 'had come', as well as the evaluative adverb 'softly'. Most strikingly there is also the direct question 'how far?' indicative of not just a perceptual subjective stance, but of a subjective voice.

The second paragraph of the opening poses similar problems as there is no character yet on stage:

Ah-Aah! sounded the sleepy sea. And from the bush there came the sound of little streams flowing, quickly, lightly, slipping between the smooth stones, gushing into ferny basins and out again; and there was the splashing of big drops on large leaves, and something else what was it? - a faint stirring and shaking, the snapping of a twig and then such silence that it seemed someone was listening (Mansfield, 'At the Bay', 201).

Many of the adjectives and adverbs here convey not just a description, but an evaluative stance too. Significantly, there is an instance also of the indefinite pronoun 'something', which signals that the observer is internally located and hasn't got full knowledge of what is going on in the scene. The direct question reinforces this limited perspective, while also being strongly suggestive once again of both a visual perspective and of a subjective voice too. 
Some of the other features on Fludernik's list appear later in the opening of the story:

Round the corner of Crescent Bay, between the piled up masses of broken rock, a flock of sheep came pattering (Mansfield, 'At the Bay', 201).

There ahead was stretched the sandy road with shallow puddles [...] Then something immense came into view; an enormous shock-haired giant with his arms stretched out. It was the big gum tree outside Mrs. Stubbs's shop [...] (Mansfield, 'At the Bay', 202).

Then pushing, nudging, hurrying the sheep rounded the bend and the shepherd followed them out of sight (Mansfield, 'At the Bay', 202).

As Fludernik rightly acknowledges, there is one character who does appear on 'the stage' of the narrative - the shepherd - but he cannot be made the focaliser as he is also described externally:

And then in the rocky gateway the shepherd himself appeared. He was a lean, upright old man, in a frieze coat that was covered with a web of tiny drops, velvet trousers tied under the knee, and a wideawake with a folded blue handkerchief round the brim (Mansfield, 'At the Bay', 202).

More importantly, the shepherd is absent on the scene for a page and a few lines of focalised description at the start. When he does appear, it is in fact possible to attribute a small section of focalised description which contains some of Fludernik's subjectivity signals quoted above:

The shepherd stopped whistling; he rubbed his red nose and wet beard on his wet sleeve and, screwing up his eyes, glanced in the direction of the sea. The sun was rising. It was marvellous how quickly the mist thinned, sped away, dissolved from the shallow plain, rolled up from the bush and was gone as if in a hurry to escape; [...] The far-away sky - a bright, pure blue - was reflected in the puddles, and the drops swimming along the telegraph poles, flashed into points of light (Mansfield, 'At the Bay', 202).

This section recording the perceptions of an observer on the scene is framed by what would be considered a classic introductory sentence to represented perception (Brinton, 1980). A perception verb, such as 'glance' in this example, prepares the context for reading what follows as the perceptions of the character. The problem, however, with this interpretation is that the above sentences that otherwise contain perception markers ('was rising', 'sped away', 'the far-away sky') are also far too poetic to be attributed to the shepherd's consciousness. The evaluative and poetic language in them ('marvellous', 'as if in a hurry to escape', 'a bright, pure blue', 'flashed into points of light') not only makes it difficult to align them with the shepherd's point of view, it also poses a problem for Banfield's definition of 'the empty centre' as a technique recording pure perception without any evaluation that would imply a reflective consciousness. While Brinton (1980) revises somewhat Banfield's definition of pure perception as necessarily belonging to non-reflective consciousness and suggests that elements of reflection and evaluation are possible in represented perception, in examples of 'the empty centre' technique it is these elements that create further difficulty with the interpretation and categorisation of the technique. This is because an evaluative stance or an evocation of psychological states without a thinking subject to whom they can be attached are more problematic than pure perception. 
Fludernik further argues that making a camera the observing point in these perceptual passages is not strictly possible, because the deictic position in the interludes in The Waves moves 'from the seashore to the garden to inside the bedroom' and perhaps the same is true in part for the opening of Mansfield's story (Fludernik, 1996: 197). The deictic centre in it is not totally fixed to one spatial position.

In her review of scholarship on 'the empty centre' phenomenon, Fludernik draws a parallel between Banfield's theory and Stanzel's discussion of what he calls 'reflectorisation of the teller character' (1984: 168). Together with an example from Mansfield's story 'The Garden Party', which constitutes a different kind of problematic use of free indirect style, 'Stanzel groups under this category examples similar to Banfield's mainly perceptual variety of free indirect style which he studies in the opening of Thomas Mann's story 'Tristan' and with a brief reference to 'At the Bay'.

Stanzel's theory of different narrative situations does not accommodate easily examples of the empty centre, because the teller-character figure in his taxonomy occupies an omniscient position outside the story, at a narrative distance, and is typical of the authorial narrative situation, or the first-person narrative situation with dominance of the narrating self (Stanzel, 1984: 169-170). This teller-character figure is opposed to the reflector-character figure which is typical of the figural narrative situation or the first-person narrative situation with dominance of the experiencing self, where the narrative is filtered through the point of view of a character and the deixis is proximal and aligned with a participating figure in the narrative. Thus, Stanzel has to break the neat distinction between teller-characters and reflector-characters in order to accommodate the examples in which reflectorisation occurs, when there is no character on stage to whom to ascribe the subjectivity markers of the language:

Because the reflectorised teller has no existential basis in this story he must be considered a transformation of the teller-character. Making an authorial narrator think and speak as if he were one of the characters of the story is called reflectorisation (Stanzel, 1984: 172).

Thus, Stanzel is pushed to accept that a non-personalised and impartial narrator of the kind we find in Modernist fiction, a narrator who is hidden from view in an otherwise figural narrative, has to be brought back into the discussion as someone through whom the narrative can be focalised.

According to Fludernik, neither Banfield nor Stanzel succeed in finding a satisfactory explanation for 'the empty centre' technique: Banfield because she ignores examples of reflective evaluation; Stanzel, because he 'has to posit a narrating persona in textual circumstances that do not warrant the existence of a teller figure' (Fludernk, 1996: 196). Fludernik argues that '[the] figure' to which the subjectivity markers can be ascribed 'operates as a reflector character in the sections from The Waves, but it can develop into a teller with speaker functions in its own right', because instances of unattributable free indirect style can manifest the whole range of modes included in the style: from pure perception to reflective evaluative representations. This new subjectivity is neither a character in the story nor a subjective narrator. Rather, for Fludernik, ' $[\mathrm{t}]$ he crucial switching point between the reflector figure and the emergence of a teller is the pronoun you' (1996: 197) which we saw can and does appear in Mansfield's opening of 'At the Bay'. Thus, for her the instances of the second person pronoun 'you' in 'empty centre' passages are a significant and indicative feature of the technique and can offer a clue as to its status. On these occurrences of the second person pronoun Fludenrik builds her own theory of 'the empty centre', according to which: 
[...] this technique is meant to evoke not the narrator's perceiving consciousness - the story ['At the Bay'] has no narrator figure at all, at best an implied author who is responsible for the textual arrangements - but the reader's. Just as, in figural narrative, the reader is invited to see the fictional world through the eyes of a reflector character, in the present text the reader also reads through a text-internal consciousness, but since no character is available to whom one could attribute such consciousness, the reader directly identifies with a storyinternal position (1996: 201).

In Fludernik's theory, the position of the observing consciousness is thus ascribed to the reader, or as she explains: 'This text-internal reader position, naturally, is a projection into the empty deictic centre' (1996: 201). The second person pronoun in Mansfield's text acts, according to her, both as a signal of 'free indirect discourse' and 'as an inducement to reader empathy, banking on the you's quality of address' (1996: 201). Undoubtedly, narrative 'you' in any one of its functional uses does implicate the reader, more or less (in)directly, transforming it into what Herman calls 'doubly deictic you' (1994). Fludernik also claims to resolve the paradox of impersonality inherent in Banfield's 'empty centre' theory by arguing in contrast 'for a model of the reading process in which the reader takes an internal position with regard to the represented events, as if she were a witness rather than a mere camera eye' (1996: 201).

Interestingly, Fludernik criticises Stanzel for collapsing ontological levels when he ascribes to the extradiegetic narrator qualities of a reflector, but if these qualities are ascribed to the reader and the reader is assumed to occupy a narrative internal position, the same transgression of ontological boundaries occurs. Her proposal, then, of transforming the reader into a reflector is neither more economical, nor more theoretically elegant than what Stanzel had proposed. However, her suggestion that the second person pronoun holds the key to the correct narratological analysis of 'the empty centre' is certainly worth pursuing, albeit not in a literal sense which implies that because the pronoun 'you' seems to address the reader amongst other things, it necessarily attaches to the reader, as a deictic centre, all of the unresolved deixis and features of a narrative internal viewpoint exhibited by passages of 'the empty centre' technique.

2. The second person pronoun

For the reader, as indexed by the second person pronoun, to become the deictic centre in such passages they must occupy the position of focaliser. It is, however, somewhat problematic to ascribe this position to a second person addressee for the entire opening of 'At the Bay', because the second person pronoun does not feature that prominently throughout the passage and in general, although generalised second person pronouns do occur in passages of 'empty centre' description, they are not that frequent. In fact, there are only three instances in Mansfield's opening of 'At the Bay':

The big bush-covered hills at the back were smothered. You could not see where they ended and the paddocks and bungalows began (Katherine Mansfield, 'At the Bay', 201).

It looked as though the sea had beaten up softly in the darkness, as though one immense wave had come rippling, rippling - how far? Perhaps if you had waked up in the middle of the night you might have seen a big fish flicking in at the window and gone again... (Mansfield, 'At the Bay', 201). 
Apart from their low frequency, second person pronouns in such passages do not address a personalised entity, albeit that of the reader. This 'you' is clearly not the personalised 'you' of second person narrative which is a protagonist in the story. It is not the extradiegetic and personalised 'you' of the Jane Eyre type addresses of the kind 'you, gentle reader'. If Fludernik proposes to make it a deictic centre in 'empty centre' passages, it might be difficult to interpret it as such, if it is not a 'you' attached to a discernible personality in the narrated world. The problem that this new theory poses seems to me to be similar to the problem encountered by Stanzel - that a non-personalised narrator starts speaking and acting as a reflector.

In other words, while deictic orientation from the point of view of a third person character within the narrative world is relatively unproblematic, the 'you' in Fludernik's examples is not a narrative internal subjectivity that is any more definable than Banfield's 'empty centre', or any more legitimately theorisable than Stanzel's reflectorised narrator. The possibility of implicating the reader in this second person pronoun, therefore, has to be investigated more carefully, because the paradoxes faced by Banfield and Stanzel seem to me to remain, unless we find a linguistically sounder way of unpacking the significance of the second person pronoun. In order to do this, I will examine some treatments of generalised or impersonal 'you' as proposed in the pragmatics literature.

In the taxonomy, designed by Gast et al., the second person pronoun can either be used: when a claim is made about the addressee only - personal uses of the second person; or in generic, generalised, impersonal uses (Gast et al., 2015: 2). Gast et al. draw a further distinction between addressee-inclusive uses of the second person impersonal pronoun and addressee-exclusive. In the latter case, because the claim made in the sentence does not strictly hold of the addressee, the use of the second person impersonal pronoun is called 'simulated', 'because the addressee is invited to engage in simulation' (Gast et al., 2015: 2).

It is clear that Mansfield's 'you' does not make a personal address to a protagonist, a narratee. It is also difficult to qualify it as a typical generic use of the second person, because it does not appear in a prototypical generic sentence of the kind 'You shouldn't drink and drive' or 'You always know when your children are lying to you'. Along the parameter of inclusivity/exclusivity of the addressee, it is, strictly speaking, addressee-exclusive, because the reader cannot be situated inside the story world, or even in that precise location in the real world (though in reality this may be possible).

The second person 'you' in Mansfield's story is very much situationally particular, while at the same time it is impersonal." As such, it is not of the category 'valid' uses of the second person, it is 'simulated'. So, how does this simulation work and what are its effects?

Wales (1996) has pointed out that the second person pronoun 'you' is frequently used as an 'egocentric' marker, i.e. to refer to the speaker's own personal experiences. Indeed, it is well established in the pragmatics and discourse literature that the impersonal second person primarily refers to the speaker or includes the speaker in its reference. Or as Bredel puts it: "You can say you to yourself" (2002). Speakers, as Bredel claims, choose the impersonal 'you' in self-reference for a variety of reasons, but the overall effect of this choice is that: 'By using a term that tends to include the hearer, [the speaker] hands over the experiences to the hearer or, at least, evokes the hearer's participation in the events' (2002: 175). For Siewierska, in impersonal uses of 'you', 'While the speaker is included among the set of referents, the emphasis is on the addressee, who is directly 
invited to imagine himself in the situation or event expressed by the speaker and thus share in the world view being presented or entertained' (2004: 212).

Commenting on the differences and similarities between 'you' and other generic terms, such as 'people', 'one', 'a person', Berry claims that: 'Compared to [these alternatives] you brings the events described to addressees, whether or not they are or could actually be participants in them; it makes the text more "personal"' (2009: 31). On these grounds, he even comments on the inappropriateness of the label 'impersonal' which Siewierska (2004) applies to such uses of 'you'.

Kluge proposes that all uses of 'you' can be situated on a continuum with five reference points: 1. I, the speaker (hiding behind 'you'); 2. I, the speaker, as a representative of a larger entity; 3. Anyone; 4. You, the person in front of me, as a representative of a larger entity; and 5. You, the person in front of me (= term of address) (2016: 504). According to her corpus which includes examples from a variety of European languages, when a speaker uses the general 'you', they want to 'present[.] his or her own experience as something generalizable, comparable to the experience of others' (2016: 504). These attempts often occur at important points in the discourse, e.g. when one of her speakers switches to the generic pronoun in German 'precisely when he recalls having to make an important decision on how to deal with backlashes [...] thereby represent[ing] this life-changing moment as something generalisable, possibly also applicable to the interviewer and the reader of the article' (2016: 510):

The following months were hard, as if some part of my psyche would punch me in my face on a daily basis. And then you begin to ask the questions that only you can answer for yourself: who are you more likely to give credit to, to the daily life punches or to your own sense of self-esteem? (Kluge, 2016: 509).

Emotionally significant moments in the narrative can, thus, elicit the use of general 'you'. This finding is comparable to Demjén's analysis of Sylvia Plath's Smith Journal, providing a record of her own life, which similarly establishes that 'second person narration has a tendency to correlate with emotional depth' and significant events (2011: 9).

Another interesting finding of Kluge's research is that across all her data, 'the generic seconds are very frequent in narratives', because as she explains 'narratives often serve as a means to transport an interlocutor to a specific scenery, in order to mentally take the position of the narrator or of a particular character' (2016: 508). iii Thus, the generic 'you' pronoun can index the speaker, as well as the interlocutor, without being specifically addressed to the interlocutor, and it plays an important role in eliciting the interlocutor's empathy.

Hrisonopulo has also claimed a double indexicality for personal pronouns, according to which 'as referential items, personal pronouns perform the function of pointing to speech-event participants/non-participants', but 'as non-referential items' - the function of 'indication of the speaker's internal states, experiences and/or communicative activities' (2007: 244). One of her examples of an impersonal use of 'you' resembles Mansfield's and is also drawn from a literary text:

Christopher Dawe held up a hand. 'Just one moment. Tell me how he moves. [...] How he moves. Walks, for example.' 'Fluidly,' Angie said. 'You could say he almost glides.' (D. Lehane, Prayers for Rain; cited in Hrisonopulo, 2007: 249). 
The modality of the sentence in which 'you' appears is one element of similarity with Mansfield's context of use of 'you'. According to Hrisonopulo:

[...] the use of you in the statement of the speaker's own (tentative) opinion indicates that the speaker [...] is inviting the addressee [...] to join her in making perceptual judgements about the person being discussed. At the same time, the pronoun you invokes the speaker as the viewer and thus as the one who can only predict the possibility for the addressee to share a particular point of view, not impose it in a straightforward and certain manner (2007: 249).

In Hrisonopulo's view (2007), when used non-referentially, 'you' points to the speaker, but at the same time establishes a distance from the speaker which accounts for its generalising meaning. However, even in these contexts, 'you' retains part of its deictic and referential meaning and involves the hearer in sharing the experience of the speaker. Kitagawa and Lehrer call this 'a sense of informal camaraderie' which is created 'precisely because the speaker assigns a major "actor" role to the addressee' (1990: 752).

All of these studies, building on real discourse data, illustrate the 'simulation' uses of the second person pronoun that Gast et al. identify. Their own two examples from footballers' interviews provide further evidence of the simulated uses of 'you' in discourse:

As a forward you have to be selfish if you want to score goals (Gast et al., 2015: 2).

As a goal keeper you never want to hear that you are going to penalty kicks because it is a 50-50 shot and you have the team on your back (Gast et al., 2015: 10).

On Gast et al.'s interpretation:

The attitude of solidarity associated with impersonal uses of the second person can probably be attributed to the very fact that the addressee engages in simulation - that she accepts the speaker's invitation to simulate - and the resulting attitude of joint empathy (2015: 11).

Thus, in addition to the semantic meaning of the impersonal use of 'you', which 'at a propositional level' Gast et al. define as 'abstraction and/or generalisation', there is a rich layer of pragmatic meanings which encompass the implication of 'solidarity between the speech participants' 'at an interactional (social) level' and the implication of 'empathy with the category over which a generalisation is made' 'at an expressive level' (Gast et al., 2015: 5).

These naturally occurring discourse examples amply demonstrate that impersonal 'you' is very common indeed in spoken language and may be associated with a lower level of formality, as opposed to 'one', for example (Berry, 2009; Biber et al. 1999). Its referential scope can, and most often does, include the speaker. Put simply, if we were to follow the logic of cognitive narratologists, when theorising narrative, which requires them to find parallels with real-life situations of storytelling, we have to acknowledge that a disembodied 'you' cannot exist if there is no ' $I$ ' who is referring to, or addressing, them. Or, according to Fludernik's process of 'naturalisation', readers will be seeking the most realistic explanation for the occurrences of ' $y o u$ ', as well as for the attribution of the perspective in 'empty centre' passages, and an explanation that a 'you' can exist without an ' $\mathrm{l}$ ' does not seem plausible. Even in narratives written entirely in the 'you' mode, where the second 
person is a specific and personalised character, as Fludernik herself notes: 'Among the more apparent deictic qualities of you that cry out for application to a fictional context, one can note the involving, dialogic function of you' which would necessarily implicate the first person speaker in the dyad (1994: 471).

The real discourse data show, as Fludernik suggests, that the empathy-inducing potential of 'you' is necessarily there. This is what makes the choice of 'you' as a general term such a preferred practice. Inevitably, because of the addressee-oriented meaning of 'you', even its generic or impersonal uses implicate the conversational partner in what is being described. Often this would happen at crucial points of important decision-making, or at points of a highly emotionally-charged experience. Speakers opt for the impersonal 'you' in order to make the addressee feel more involved or make them imagine how it would feel if they were undergoing the experiences described. But importantly, a lot of the time, the real referent of 'you' is the first person speaker. It is their specific personal experience that is being recounted and transformed from an isolated and personal first-person account into what can potentially apply to the addressee, or anyone else. Thus, most impersonal uses of 'you' in discourse implicate not only the addressee in the experience, but also the speaker, albeit indirectly.

\section{The Modernist narrator}

In Mansfield's text, then, the pronoun 'you' is an interactional and expressive signal which, Fludernik is right to observe, invites the reader to occupy a narrative-internal deictic and emotive position, but it is not literally either personal or 'addressee-inclusive'. For its addressee-exclusive simulation to work we still need to posit a speaker who seeks the 'solidarity' and 'empathy' encoded in the pragmatic meanings of the impersonal second person pronoun.

Stanzel's position, thus, comes closer to what I think is the case in 'empty centre' passages: the narrator who is hidden from view in the rest of such narratives, which are almost entirely composed of the represented consciousness of characters, still remains hidden from view, i.e. not personalised, in reflectorised descriptions with no character on stage. But his or her presence is felt more strongly as the description implies a narrative internal observing consciousness. As shown by Fludernik and my analyses, this observing consciousness does not simply reflect the physical world as per Banfield's analysis, it also evaluates this world. It is also a consciousness that engages the reader interpersonally and expressively.

The other classic example of 'the empty centre' technique - Section II 'Time Passes' of Virginia Woolf's To the Lighthouse - offers further insight into the status of this Modernist narrator. ${ }^{\text {iv }}$ The greater part of this section is, according to Leaska, 'a short poetic interlude' (1970: 114), and 'this Iyrical [...] section' (1970: 121) is attributed by him to the narrator, or as he says it is 'given primarily through the Omniscient Narrator' (1970: 114) and it is 'governed by the Omniscient Narrator' (1970: 121). Although Leaska's choice of terminology is not entirely accurate since the narrator is anything but omniscient in this section, it is significant that he too attributes the section to the narrator.

This middle section of Woolf's novel offers a description of the Ramsays house, at which all characters stayed in the first part of the book and where they reconvene after Mrs Ramsay's death in the final part of the book. But at this point the house is uninhabited; apart from the eventual 
appearance of Mrs McNab, who looks after the house, there is no character on stage who can act as a focaliser:

So with the lamps all put out, the moon sunk, and a thin rain drumming on the roof a downpouring of immense darkness began. Nothing, it seemed, could survive the flood, the profusion of darkness which, creeping in at keyholes and crevices, stole round window blinds, came into bedrooms, swallowed up here a jug and a basin, there a bowl of red and yellow dahlias, there the sharp edges and firm bulk of a chest of drawers. (Woof, To the Lighthouse, 137)

Already at the opening of this section a narrative internal and subjective observation point is suggested by the perception verb 'seemed' and the deictic 'came'. These, together with the lyrically evocative metaphors, create a sense of a subjective speaker being present on stage. The whole section continues to be deictically focalised and subjectively perceived through a particular narrative internal observation point:

Nothing it seemed could break that image, corrupt that innocence, or disturb the swaying mantle of silence which week after week, in the empty room, wove into itself the falling cries of birds, ships hooting, the drone and hum of the fields, a dog's bark, a man's shout, and folded them round the house in silence (Woolf, To the Lighthouse, 142).

When darkness fell, the stroke of the Lighthouse, which had laid itself with such authority upon the carpet in the darkness, tracing its pattern, came now in the softer light of spring mixed with moonlight gliding gently as if it laid its caress and lingered stealthily and looked and came lovingly again. But in the very lull of this loving caress, as the long stroke leant upon the bed, the rock was rent asunder [...] (Woolf, To the Lighthouse, 145).

The house was left; the house was deserted. It was left like a shell on a sandhill to fill with dry salt grains now that life had left it (Woolf, To the Lighthouse, 150).

What power could now prevent the fertility, the insensibility of nature? (Woolf, To the Lighthouse, 150).

The frequent occurrences of 'seemed' coupled with the temporal deictic 'now' and the deictic verb 'came' locate the observer within the scene. These features of represented perception are part of the repertoire of free indirect style, although as in the Mansfield passages, they cannot be attributed to anyone physically present on the scene. Neither can we attribute the direct questions, which more explicitly project a voice, rather than just an observer's perception. The highly lyrical quality of this section, created by the poetic metaphors, also invites an interpretation of a subjective point of view. Most likely, readers would naturalise such passages as narratorial, though on occasion there are inanimate elements of the environment which are personalised. Critics frequently allude to the near personalisation of 'certain airs', which almost seem to act as a focaliser in some parts of the description:

Nothing stirred in the drawing-room or in the dining-room or on the staircase. Only through the rusty hinges and swollen sea-moistened woodwork certain airs, detached from the body of the wind (the house was ramshackle after all) crept round corners and ventured indoors. Almost one might imagine them, as they entered the drawing-room, questioning and 
wondering, toying with the flap of hanging wall-paper, asking would it hang much longer, when would it fall? Then smoothly brushing the walls, they passed on musingly as if asking the red and yellow roses on the wall-paper whether they would fade, and questioning (gently, for there was time at their disposal) the torn letters in the wastepaper basket, the flowers, the books, all of which were now open to them and asking, Were they allies? Were they enemies? How long would they endure? (Woof, To the Lighthouse, 138).

We can see that the 'certain airs', although mostly described by an external observer, are also attributed human-like characteristics - they can perform verbal processes of questioning and asking and they can move around the house 'musingly', thus endowing them with the ability to think as well. Some of the deictic and subjective markers can be aligned with them - 'gently, for there was time at their disposal', 'now' and the direct questions. Especially interesting is the parenthetical phrase 'gently, for there was time at their disposal', because it is a classic example of Woolf's use of parenthesis to offer a glimpse into someone's consciousness, while embedding it in another type of discourse. Except on this occasion the personified entity cannot possess a consciousness. But as well as focalising some of the scene through what appears to be the viewpoint of the 'airs' detached from the wind, this passage also blends in the subjective perspective of the person describing the scene through the other evaluative and conversational parenthetical phrase 'the house was ramshackle after all'. And after 'the little airs mount[.] the staircase', another sentence of free indirect style seems to blend the projected voice of 'the airs' and the subjective voice of the lyrical observer: 'But here surely, they must cease' $(T L, 138)$. The spatial deictic 'here', together with the modality expressed by the modal verb 'must' and the modal adverb 'surely' strongly imply both a physical perspective on the scene and a subjective reflective voice.

A significant feature worth noting in the above passage is the use of another generic, or impersonal, pronoun - 'one': 'Almost one might imagine them, as they entered the drawing-room...' (TL, 138). This particular impersonal pronoun is typical of Woolf's style in general and it does crop up frequently in her free indirect style too. Two further examples from 'Time Passes' demonstrate that 'one' is also typical of her 'empty centre' section of To the Lighthouse:

[...] there was scarcely anything left of body or mind by which one could say 'This is he' or 'This is she' (Woolf, To the Lighthouse, 138).

Here one might say to those sliding lights, those fumbling airs, that breather and bend over the bed itself, here you can neither touch nor destroy (Woolf, To the Lighthouse, 138)

On such occasions Woolf, too, seems to invite the reader to imagine or be involved in the scene, albeit more indirectly than Mansfield, because the second person always necessarily implicates the reader in its semantic scope.

But interestingly, Mansfield also resorts to generic 'one' in the opening of 'At the Bay':

Now the leaping, glittering sea was so bright it made one's eyes ache to look at it (Mansfield, 'At the Bay', 202).

In a discussion of the meaning of generic 'one', Moltmann writes: 
First-person-oriented genericity is a form of generalisation that is associated with the meaning of a wide range of expressions, and most explicitly in English with generic one. It is clearly also a central cognitive notion. First-person-oriented genericity leads to self-locating beliefs and assertions, but it involves self-reference in a quite different way than familiar cases of pronouns interpreted de se, involving the notion of a self that can detach itself from the actual person (Moltmann, 2010: 471).

The semantics of 'one', thus outlined, imply a detached reference to the self. The individual experience or beliefs of the first person are still indexed, but there is a sense of detaching the experience from the very personal and specific level and making it applicable to people more generally. As with 'you', the crucial element of 'one' is still self-reference. At the same time, both generic pronouns, more or less (in)directly, would seem to implicate the reader into the scene, inviting them to experience it from within the narrative.

Woolf's narrator goes further in implicating her own voice into this 'empty centre' section:

It seemed now as if, touched by human penitence and all its toil, divine goodness had parted the curtain and displayed behind it, single, distinct, the hare erect; the wave falling; the boat rocking, which did we deserve them, should be ours always. But alas, divine goodness, twitching the cord, draws the curtain; it does not please him; he covers his treasures in a drench of hail, and so breaks them, so confuses them that it seems impossible that their calm should ever return or that we should ever compose from their fragments a perfect whole or read in the littered pieces the clear words of truth. For our penitence deserves a glimpse only; our toil respite only ( $T L, 139)$.

Alongside, the narrative-internal verb of perception and deixis- 'seemed' and 'now' - Woolf here uses another generic pronoun - 'we'. If it was remotely possible to exclude the first person from the referents of 'you' and 'one', here it is certainly impossible. And again, the semantic scope of 'we' seems to include the addressee. Although the passage switches to present tense, some of it does not sound as if it is making a universal generic statement about human experience; part of the passage is clearly contingent on the specific experience of the scene of the abandoned house and thus questions whether the present tense is indeed the generic present.

What this further passage demonstrates is that the narrator cannot be excluded from the referents of generic or impersonal pronouns appearing in 'empty centre' passages. Indeed, both Mansfield and Woolf have commented on the writing experience in terms which strongly implicate their narratorial voices into their focalised narratives.

In a letter to her friend, the painter Dorothy Brett, Mansfield says:

When I write about ducks I swear that I am a white duck with a round eye, floating in a pond fringed with yellow blobs and taking an occasional dart at the other duck with the round eye, which floats upside down beneath me. In fact this whole process of becoming the duck (what Lawrence would, perhaps, call this 'consummation with the duck or the apple') is so thrilling that I can hardly breathe, only to think about it. [...] There follows the moment when you are more duck, more apple or more Natasha than any of these objects could ever possibly be, and so you create them anew (Stead, 1977: 84). 
This empathetic immersion is what I think underlies the representation of the landscape in the opening of 'At the Bay'. Mansfield not only projects herself into the natural scene of the early morning at the bay, she explicitly personifies elements of nature, projects an anima into inanimate or non-human entities. The subjective representation of the natural scene, then, is not an instance of representing 'the world without a self', but an instance of infusing selfhood into the world.

This is paralleled by Woolf's personification of the airs in the middle section of To the Lighthouse. Woolf explicitly singles out this middle section 'Time Passes' as 'this impersonal thing' (1978: 109), 'the most difficult abstract piece of writing' (1978: 118), but also one more lyrical and more directly expressive of her authorial-narratorial voice. She says about the novel as a whole: 'It is all in oratio obliqua', a statement that would imply the pervasive use of free indirect style, but then adds: 'Not quite all; for I have a few direct sentences. The lyric portions of To the Lighthouse are collected in the 10-year lapse and don't interfere with the text so much as usual'. (Woolf, 1978: 131).

It would seem, then, that the more detached 'one', in both Mansfield's and Woolf's examples of 'the empty centre' technique, combined with proximal deictic references, experiential aspectual choices and the interpersonal and empathetic effects of the pronoun 'you', as well as its juxtaposition with the clearly first person generic 'we', create a paradoxical effect in Modernist narratives of immersion and detachment at the same time. This double effect of subjectivity and objectivity seems to capture a tension that Modernist writers must have felt between the subjective, narrative-internal voice of a narrator with diminished authority and the objective and impersonal voice of a narrator who represents character consciousness omnisciently.

In ontological and epistemological terms, this narrator can no longer be unequivocally considered an omniscient extradiegetic figure, but must also be capable of embodying a figure with limited knowledge of the narrative world and a specific deictic and evaluative stance which is not impersonal.

It is in these very terms that Auerbach describes Woolf's narrator in his seminal Mimesis:

[...] here too we are not dealing with objective utterances on the part of the author in respect to one of the characters. No one is certain of anything here: it is all mere supposition, glances cast by one person upon another whose enigma he cannot solve (1953: 532).

It is significant that Auerbach's assessment of the status of Woolf's narrator here is done in relation to a passage of description not of the physical world, but of one of the characters - Mrs Ramsay. After reflecting on the stocking she is knitting for the lighthouse keeper's boy she says:

'It's too short,' she said, 'ever so much too short.'

Never did anybody look so sad. Bitter and black, half-way down, in the darkness, in the shaft which ran from the sunlight to the depths, perhaps a tear formed; a tear fell; the waters swayed this way and that, received it, and were at rest. Never did anybody look so sad (Woolf, To the Lighthouse, 35).

The description that follows Mrs Ramsay's utterance is, according to Auerbach, provided as if by someone present on the scene and observing Mrs Ramsay. But it leaves the reader uncertain as to: 
Who is speaking in this paragraph? Who is looking at Mrs Ramsay here, who concludes that never did anybody look so sad? Who is expressing these doubtful, obscure suppositions? about the tear which - perhaps - forms and falls in the dark, about the water swaying this way and that, receiving it, and then returning to rest? There is no one near the window in the room but Mrs Ramsay and James. It cannot be either of them, nor 'the people' who begin to speak in the next paragraph (Auerbach, 1953: 531).

Auerbach is right to note that the statements are infused with both modality and exaggeration ('Never did anybody look so sad', 'perhaps'), two indices of free indirect style, and as such they cannot be easily categorised as the discourse of the omniscient narrator. The difficulty, as he explains, lies in the fact that the authorial narrator should know everything about her characters and in this passage 'the author certainly does not speak like one who has a knowledge of his characters in this case, of Mrs Ramsay - and who, out of his knowledge, can describe their personality and momentary state of mind objectively and with certainty' (1953: 531).

As Auerbach notes, Woolf 'did not identify [the paragraph] through grammatical and typographical devices as the speech or thought of a third person', therefore, 'one is obliged to assume that it contains direct statements of her own' (1953: 531). But if that is the case, Woolf 'does not seem to bear in mind that she is the author and hence ought to know how matters stand with her characters' (1953: 531). Ultimately, for Auerbach:

The person speaking here, whoever it is, acts the part of one who has only an impression of Mrs Ramsay, who looks at her face and renders the impression received, but is doubtful of its proper interpretation (1953: 531-532).

That this position is not allowed to be assumed by the narrator in Modernist fiction is perhaps more a failing of our narratological models than an inconsistency on the part of writers. Woolf's narrator here, like her narrator in 'Time Passes' and Mansfield's narrator in 'At the Bay', speaks as a character endowed with subjectivity and limited in their perspective and knowledge by their participation in the narrative world. This is the conclusion reached in Auerbach's discussion:

[...] the tone indicates that the author looks at Mrs Ramsay not with knowing but with doubting and questioning eyes - even as some character in the novel would see her in the situation in which she is described, would hear her speak the words given (1953: 535).

This example, therefore, is of the same nature as the examples of 'the empty centre' technique reviewed earlier and what both these types of examples demonstrate is that the Modernist narrator can and does act like a character, in spite of their otherwise assumed omniscience which allows them to represent their characters' consciousness. While Stanzel does accommodate the subjective voice of a narrator acting like a character in his model, he, like Fludernik, includes under such instances of reflectorisation the representation of a collective voice in free indirect style. But examples, such as the one Stanzel gives from 'The Garden Party' are representative of a different kind of phenomenon in the various manifestations of free indirect style:

That really was extravagant, for the little cottages were in a lane to themselves at the very bottom of a steep rise that led up to the house. A broad road ran between. True, they were far too near. They were the greatest possible eyesore, and they had no right to be in that 
neighbourhood at all. They were little mean dwellings painted a chocolate brown [...] (Mansfield, 'The Garden Party', 245).

Stanzel's and Fludernik's argument that these thoughts can't be attributed to Laura's sister, Jose, and so they must necessarily be attributed to their mother, who is not present, or the Sheridans collectively, might be right, ${ }^{ }$but this does not necessarily mean that here we have a case identical to 'empty centre' passages, because we have to read such representations as the narrator's mimicry of the voices and attitudes of characters who are not present. While this type of difficult example of free indirect style involves an ironic echo of characters' beliefs, the complexity of 'the empty centre' technique and of Auerbach's example from To the Lighthouse lies in the fact that the narrator acts like a subjective observer from within the narrative world.

The echoic representation of a collective voice has its historical precedent in the realist novel, where similar ironic representations of a collective voice can be found (e.g. the collective voice of the townsfolk at the beginning of Middlemarch). Fludernik tries to distinguish between these and the later Modernist examples of echoing a collective voice by introducing the term 'figuralisation' to account for 'the reflectoral and empathetic style' of Modernist examples, as opposed to 'the narratorial and (implicitly) dissonant tone of 'reflectorisation' in the earlier novel (1996: 202). But in spite of this refinement of Stanzel's categories, the disparity between the representation of a collective voice and opinion which cannot be attributed to a character 'on stage' and the focalised narrative-internal representations of 'the scene' in 'empty centre' passages remains and 'empty centre' passages align more easily with the subjective and uncertain description of Mrs Ramsay in Auerbach's example.

The subjective lyrical narrator of Modernist fiction is for Auerbach a historically new phenomenon. According to him, in Modernist fiction more generally, there is an 'obscuring and even obliterating' of 'the impression of an objective reality completely known to the author', achieved by the author 'representing herself to be someone who doubts, wonders, hesitates, as though the truth about her characters were not better known to her than it is to them or to the reader' (1953: 535). And this new position that the Modernist narrator can take is unique to the period and distinct 'entirely from that of authors who interpret the actions, situations, and characters of their personages with objective assurance, as was the general practice in earlier times', where Auerbach places writers, such as 'Goethe or Keller, Dickens or Meredith, Balzac or Zola', all writers with 'certain knowledge', who although capable of using free indirect style, did not represent their own viewpoint in free indirect style as if they were one of the characters (1953: 535).

The critical commonplace, then, that Modernist writing undermines the authority of the narrator, and as a consequence any authority of an objective truth or reality, by fragmenting the narrative into a multitude of different viewpoints, should also be seen to be evidenced, in even more complex ways, in the paradoxical status of the Modernist narrator. The tension that I have traced here, of trying to write as a narrator who is both lyrical and personalised and impersonal and omniscient at the same time, presents that further layer of complexity that has hitherto not been discussed.

This new status of the Modernist narrator is, I believe, an embodiment of Bakhtin's author/narrator who co-exists on the same plane with the characters and whose 'discourse about a character is organised as discourse about someone actually present, someone who hears him (the author) and is capable of answering him' (1984[1963]: 63). 
Fludernik herself sees in such Modernist reflectorised passages reviewed here a precursor to the Post-Modernist 'pseudo-orality', which makes a narrator's voice sound like a personalised skaz narrator, but which at the same time is able to represent the consciousness of characters as if from a position of omniscience. The co-existence of these two positions in Modernist narratives, one of narratorial omniscience and impartiality and one of narratorial limited knowledge and highly lyrical personalness should not be treated as an aberration that is difficult to accommodate in existing narratological models, but should be seen as a deliberately sought tension on the part of writers in the period which naturally leads to the ontological and epistemological disturbances of PostModernism.

\section{References:}

Adamson, S. (1994) 'Subjectivity in Narration: Empathy and Echo', in Yaguello, M. (ed) Subjecthood and Subjectivity, pp. 183-98. Paris: Ophrys.

Auerbach, E. (1953) Mimesis: The Representation of Reality in Western Literature, translated by Trask, W.R. Princeton, NJ: Princeton University Press.

Banfield, A. (1982) Unspeakable Sentences: Narration and Representation in the Language of Fiction. Boston: Routledge \& Kegan Paul.

Banfield, A. (1987) 'Describing the Unobserved: Events Grouped Around an Empty Centre', in Fabb, N., Attridge, D., Durant., A. and MacCabe, C. (eds) The Linguistics of Writing: Arguments between Language and Literature, pp. 265-85. New York: Methuen.

Banfield, A. (2003) 'Time Passes: Virginia Woolf, Post-Impressionism, and Cambridge Time', Poetics Today, 24(3): 471-516.

Berry, R. (2009) 'You Could Say That: The Generic Second-Person Pronoun in Modern English', English Today 99, 25(3): 29-34.

Biber, D., Johannson, S., Leech, G., Conrad, S. and Finegan, E. (1999) Longman Grammar of Spoken and Written English. Harlow: Pearson Education.

Bredel, U. (2002) '“You can say you to yourself". Establishing Perspectives with Personal Pronouns', in Graumann, C.F. and Werner, K. (eds) Perspective and Perspectivation in Discourse, pp. 167180. Amsterdam: John Benjamins.

Brinton, L. (1980) 'Represented Perception: A Study in Narrative Style', Poetics, 9(4): 363-381.

Demjén, Z. (2011) 'The Role of Second Person Narration in Representing Mental States in Sylvia Plath's Smith Journal', Journal of Literary Semantics, 40: 1-21.

Fludernik, M. (1993) The Fictions of Language and the Languages of Fiction: The Linguistic Representation of Speech and Consciousness. London: Routledge. 
Fludernik, M. (1994) 'Second-Person Narrative as a Test Case for Narratology: The Limits of Realism', Style, 28(3): 445-475.

Fludernik, M. (1996) Towards a Natural Narratology. London: Routledge.

Gast, V., Deringer, L., Haas, F. and Rudolf, O. (2015) 'Impersonal Uses of the Second Person Singular: A Pragmatic Analysis of Generalisation and Empathy Effects', Journal of Pragmatics, 88: 148162.

Herman, D. (1994) 'Textual You and Double Deixis in Edna O'Brien's A Pagan Place', Style, 28(3): 378404.

Hrisonopulo, K. (2007) 'Who Is to Believe When You Bet: on Non-Referential Indexical Functions of the Pronoun You in English', Cultural Studies Journal of Universitat Jaume I, V: 241-253.

Kitagawa, C. and Lehrer, A. (1990) 'Impersonal Uses of Personal Pronouns', Journal of Pragmatics, 14: 739-759.

Kluge, B. (2016) 'Generic uses of the Second Person Singular - How Speakers Deal with Referential Ambiguity and Misunderstandings', Pragmatics, 26(3): 501-522.

Moltmann, F. (2010) 'Generalising Detached Self-Reference and the Semantics of Generic One', Mind and Language, 25(4): 440-473.

Rundquist, E. (2014) 'How is Mrs Ramsay Thinking: The Semantic Effects of Consciousness Presentation Categories within Free Indirect Style', Language and Literature, 23(2): 159-174.

Schofield, D. (1997) 'Beyond The Brain of Katherine Mansfield: The Radical Potentials and Recuperations of Second-Person Narrative', Style, 31(1): 96-117.

Siewierska, A. (2004) Person. Cambridge: Cambridge University Press.

Sotirova, V. (2013) Consciousness in Modernist Fiction: A Stylistic Study. London: Palgrave.

Stanzel, F. (1984) A Theory of Narrative. Cambridge: Cambridge University Press.

Stead, C.K. (ed) (1977) The Letters and Journals of Katherine Mansfield: A Selection. Harmondsworth: Penguin.

Wales, K. (1996) Personal Pronouns in Present-Day English. Cambridge: Cambridge University Press.

\section{Texts:}

Mansfield, K. (1981) Selected Stories. Oxford: Oxford University Press.

Woolf, V. (1977[1926]) To the Lighthouse. London: Grafton Books.

Woolf, V. (1978) A Writer's Diary, edited by Leonard Woolf. London: Grafton Books.

Woolf, V. (1969[1931]) The Waves. London: Penguin. 


\footnotetext{
'Stanzel's example from the opening of 'The Garden Party' is one of echoing the collective voice and opinions of the Sheridans - the family on whom the story focuses. It is similar to the opening of 'At the Bay' in that it also presents a difficult case of perspective, and in this case voice, attribution. But the two passages, although grouped together under the same category by Fludernik (1996), alongside a variety of other examples, are very different in nature. 'The Garden Party' passage, as well as the opening of Mansfield's 'Feuille D'Album' also alluded to in Fludernik's discussion, are representations of collective opinion. The opening of 'At the Bay', which fits under Banfield's category of 'the empty centre' is a representation of perception that is difficult to attribute as there is no character on stage. In my analysis I will only concentrate on 'the empty centre' technique, which I consider to be distinct from any representation of a collective voice, even if this is equally difficult to attribute.

ii The terms generic, impersonal, generalised seem to be used interchangeably in the linguistics literature, though generic sentences of the kind given above are clearly different from the impersonal uses of 'you' in relation to specific situations. As Siewierska states: 'Various terms are used to refer to such forms in the literature: universal non-specific, generic, generalised human, generalised indefinite, referentially arbitrary and impersonal' and she chooses to use 'impersonal' (2004: 210).

iii This finding would seem, to an extent, to contradict Herman's strong assertion that while 'First and third person novels have obvious non-fictional counterparts in autobiography and biography', 'second person is an exclusively and distinctively literary phenomenon, its only non-fictional analogues being the pseudo-narrative forms of the cookbook, the travel guide and the self-help manual' (1994: 400). An obvious route of descent of second-person fiction can, to my mind, be found in the extensive uses of general 'you' in first-person narratives, as demonstrated by Kluge's data.

${ }^{\text {iv }}$ See Banfield (2003) for a different discussion of the representation of time and the parallels between Woolf's 'Time Passes' and Mansfield's 'At the Bay'.

${ }^{v}$ I think there is some evidence in the text for attributing this passage to Jose and interpreting it as echoic of the mother's view and possible prior discourse.
} 